\title{
THE CATEGORY OF EVALUATION IN POLITICAL DISCOURSE
}

\author{
Tatiana Ananko \\ Kyiv National Linguistic University, Kyiv, Ukraine \\ ananko926@ukr.net
}

\begin{abstract}
Political discourse is a popular area of research because it penetrates a modern society. Being usually delivered by politicians, political discourse is a complex linguistic phenomenon which is directly or indirectly aimed at distributing, exercising the political power and winning the majority of votes during elections. This article deals with the category of evaluation which is considered to be a semantic and pragmatic category and can be one of the most powerful means of influence on the audience. This study focuses on the evaluative means used by Hillary Clinton as one of the presidential candidates in the USA in her speeches during the presidential campaign. Under the Appraisal theory framework, this paper discusses a variety of meaning-making resources used by the speaker to express her evaluative involvement in communication. The categories of engagement and graduation are also analysed. The attention is also paid to the interrelations between evaluation and values. Of special interest is a wide use of metaphors as well as the semantic polarisation of evaluative components in the speeches of the politician. The results show that the attitudinal meanings are mostly conveyed by judgements.
\end{abstract}

Keywords: appraisal; evaluation; discourse; engagement; judgement.

\section{Introduction}

It is obvious that communication penetrates all spheres of human life. Communication in politics can be considered as its backbone because it helps political processes go. Communication may also help politicians make a certain impact on the society and make it function as an integrated whole. Especially it is noticeable during election campaigns when the future of the country is at stake and what is essential is vote-win. It is admitted that political discourse has considerably changed recently. It has become faster, sharper and tougher (Fitzwater, 2016, p. 6) due to the intensive use of mass media, social media and social networking. The candidates have become more personality-oriented and it means that aggressive strategies of negative evaluation are more frequently used for describing opponents. Lack of civility in political discourse during last presidential election in the USA has evoked the importance of this issue in society. Civil political discourse is known to appeal to the citizens of the country, being non-military, non-criminal and polite. Moreover, it is fixed by the regulations of the set of laws (McKeever, 2016, p. 3).

For achieving their aims politicians usually use a wide variety of tools and strategies, among which there are evaluative means, rather powerful in shaping public perceptions and awakening latent tendencies among people. The purpose of this paper is to provide a comprehensive linguistic analysis of the evaluation category widely used by one of the candidates for US presidency Hillary Clinton in her election discourse related to self-presentation and opponent-presentation strategies. Of primary importance are various evaluative means which convey the meanings of affect, judgement and appreciation within the framework of Appraisal theory (Martin \& White, 2005). The focus is also on the category of engagement represented by axiological predicates among others, as they convey the speaker's opinions and demonstrate a certain state of certainty. Of special interest is semantic polarisation as one of intensification means of evaluation. The attention is also paid to metaphorical expressions which evoke part-to-whole relations and can justify courses of political action. It makes them a fascinating area of study.

\section{Data and methodology}

The paper is based on the data from Clinton's 3 speeches and her 3 debates with Trump, which she delivered in different locations during 2016 presidential election campaign in the USA. Each speech is over 5000 words long. The data of the research comprises more than 400 lexical units expressing evaluation chosen by complete selection. The methodology employed in the study is Appraisal theory, which presents a basic framework for the linguistic analysis. Focusing mainly on semantic peculiarities of evaluation, the Appraisal theory broadens the boundaries of the analysis with discourse semantics. It means that all discourse aspects (register, tenor, participants with their communicative intentions and cognitive systems) become very important for the study of establishing and targeting evaluation. As a result, evaluative meanings are expressed at discourse level beyond the clause (Martin \& White, 2005, p. 9). In this respect, the theoretical perspective essential to the study is also the pragmatic approach to evaluation analysis (Arutyunova, 1988; Pryhod'ko, 2013; Wolf, 2002) focusing on the role of non-linguistic knowledge in utterance interpretation and the principles which constrain its use as well as on the context types for evaluation. 
Besides, the categories of engagement and graduation within the Appraisal theory correlate with the lexical-grammatical level of language strata, adding some grammatical background to the research (Halliday, 2002). The study of political discourse is strongly influenced by van Dijk's ideas (1997) on political discourse analysis which presents broader understanding of speaker's intentions for producing evaluative meanings.

\section{Results and Discussion}

\subsection{Political Discourse in Communication Continuum}

Taking into consideration the basic ideas of critical discourse analysis, which focuses on the study of political discourse in terms of reproduction of political power, power abuse or domination (van Dijk, 1997, p. 11), we generally support a recent elaboration of this theory. Modern political discourse analysis contributes considerably not only to discourse study but also to political science and other social sciences extending a critical approach (van Dijk, 1997, p. 12). The linguists focus their attention on such issues as social and political inequality resulted from political domination (Fairclough, 1995) and peculiarities of the rhetoric of political communication (Schaffner, 1995). According to van Dijk, the analysis of political discourse "should not be limited to the structural peculiarities of a text only, but also include a systemic account of the context and its relations to discursive structures"(van Dijk, 1997, p. 15).

Political discourse is a discourse of politicians (van Dijk, 1997, p. 12), it is a complex linguistic phenomenon which is directly or indirectly aimed at distributing and exercising the political power (Sheigal, 2000), and also making political decisions. It is pointed out that politicians are not the only participants in such communication. The recipients of political information, such as the public, the citizens, the voters should be also included into discourse analysis (van Dijk, 1997, p. 13). In this case, political discourse becomes public. Besides, political discourse is an institutional type of discourse, because a speaker is not usually an individual person, but s/he represents a political party, a country or a ruling establishment (Karasik, 2004, p. 281).

Political discourse is considered to be characterised by high degree of manipulation. In this aspect, the interest to its study is predetermined, firstly, by the search of optimal means of influence of politicians on the audience and, secondly, by the necessity of recognising the true intentions of the speaker and covert mechanisms of manipulation of the audience (Sheigal, 2000, p. 45).

Political discourse is seen as a form of political action and a pan of political process in politics (van Dijk, 1997, p. 14). During election campaigns, all members of the society are involved in this process and it leads to their ideological polarisation. In this case, the category of evaluation requires special attention and further analysis. By means of evaluation the prominence can be given to certain parts of the text or the talk and in such a way, the attention of the audience might be attracted and manipulated. It also makes the speakers sound more persuasive, confident and powerful.

\section{2 The Category of Evaluation: semantic and pragmatic aspects}

The category of evaluation is a rather popular object of linguistic study. Evaluation by its nature is anthropocentric, it means that the contents of evaluation reflect human nature and depend on the values and axiological norms of a person. A lot of contribution has been made to the study of evaluative aspect of linguistic persona (Karasik, 2004) in the framework of communicative linguistics; to the study of evaluative function of lexeme as a component of connotative meaning and semantic prosody as means of its employment in semantics (Sinclair, 2004); to stylistic analysis and evaluation (Short and Semino, 2008); to the use of various evaluative means with the aim of producing an impact on the addressee and getting an intended effect in pragmatics (Fraser, 1996); to interrelations between values and emotions (Mulligan, 1998); to frame construction of evaluative situation (Zhabotynska, 2013) and to the study of ideology and evaluative semantics (Malrieu, 1999) in cognitive linguistics.

Expressiveness, as a component of the connotative meaning, with the help of which a word may express a subjective attitude of a speaker to an addressee or to the communicative situation in general, is beyond the language system. It can be created only in speech accompanied by some non-verbal elements of communication, though some words may display certain pragmatic characteristics out of communicative context. In this sense, expressiveness is transferred to evaluation. Following Pryhod'ko, evaluation has a linguistic universal character, being observed in all spheres of human life. It allows to study evaluation as a complex of its linguistic and communicative peculiarities, as a semantic and pragmatic category (Pryhod'ko, 2013, p. 23).

These ideas are elaborated in the framework of the Appraisal theory as it deals, among others, with the level of tenor which is represented by power and solidarity in communication. The Appraisal theory, developed by Martin and White (2005), gives a deep insight into the language of evaluation which displays a 
wide variety of meaning-making resources used by a speaker/ writer to express personal, evaluative involvement in the text (White, 2015). According to White, the evaluative meanings give some of the mechanisms by which the interpersonal meta-function operates. They reveal the speaker's feelings, tastes and opinions with greater or lesser degree of intensity and directness (White, 2015, p. 2). An appraisal is defined as an interpersonal system at the level of discourse semantics (Martin \& White, 2005, p. 33).

The Appraisal theory suggests that the attitudes of the speakers can be expressed with the help of three axes: affect, which conveys positive or negative feelings; judgement, which concerns the attitudes towards behaviour and appreciation which involves evaluation of semiotic and natural phenomena (Martin \& White, 2005 , p. 42-43). In this aspect, it is worth mentioning that evaluation is based on the axiological values especially if appraisal is conveyed by means of judgements and appreciation. In addition, other forms of expression of evaluative meanings are taken into consideration, such as engagement, namely the means of expressing various opinions and graduation as source of intensification of evaluation.

\subsection{Evaluation and values}

Values are based on perceptions of a certain object and phenomenon. There is no direct coincidence between values and perceptions, as people of different ages/genders may have different perceptions about a number of things. But there are at least a dozen of values in the society that might be accepted as shared ones (Sillars \& Garner, 1982, p. 187). Communities are formed not simply around shared values but around shared values about communal activity (Martin \& White, 2005, p. 28). Values can be treated as one of the means of categorisation on the basis of evaluation, and the world can be described as a hierarchy of values.

Motives of evaluation and evaluation itself don't have a direct connection, though they are in a permanent empirical interrelation in the consciousness of people (Arutyunova, 1988). Following Maslow (1999), values are predetermined by certain needs in some periods of life. Presenting a positive theory of motivation, Maslow identifies basic needs of lower level (physiological needs, security) and of higher level (love, acknowledgement, cognitive needs) (Maslow, 1999, p. 46). The consideration of these needs might be crucial for the speeches of politicians if they want to win more votes.

Moreover, the cultural values are also essential for political discourse as they serve as a certain frame for election campaigns. Evaluation can be defined as speaker's objective or subjective attitude to a certain object, which can be explicitly or implicitly expressed by language means (Byessonova, 2013). The English language thesaurus is characterised by 28 concepts which occupy the nuclear position, among them are love, right/wrong, evil/good. It is pointed out that being characterised by systemic hierarchical structure, iconicity and conceptual universals, the English language thesaurus is mostly negatively marked. There are 40 concepts placed at the negative edge of the axiological scale (wrong, evil, harm, enmity, lie, treachery and others) in the comparison with 29 positive concepts and 20 mixed ones (Byessonova, 2013, p. 9). Among a number of semantic primes indicated in the English language, there are such concepts as GOOD, BAD and TRUE, which are recognised as linguistic universals. It is also pointed out that the English language is characterised by an extensive use of causative expressions and epistemic phrases and adverbs, clarifying the speaker's stance to the object of discussion (Wierzbicka, 2006).

As anthropocentric category evaluation depends on the system of shared values of a certain language community and is highly predetermined by the national specifics of the perception of the world by members of the community. As Hofstede (2011) points out, an American society is characterised by high degree of individualism, masculinity, low level of power distance, which shows great equality between community levels and creates a more stable cultural environment. It also displays low level of long-term orientation and leads to the society's belief in meeting its obligations and shows an appreciation for cultural traditions. Low level of uncertainty avoidance reflects a society which does not attempt to control all outcomes and demonstrates a high degree of tolerance for a variety of ideas and thoughts (Hofstede, 2011, p. 9). It finds its realisation in the concept of diversity widely supported in the society.

American society is known to be dedicated to the democratic values set by the Founding Fathers. Hillary Clinton as a Democratic candidate repeatedly appeals to these values in her speeches. In political discourse, the all-national values correspond to the key words, which become semantic bonds (Belova, 2003, p. 41), such as our/one nation, Founders, freedom, equality, justice, opportunity and others. They form the basic axiological frame according to which the information is completely taken in by the audience.

(1) My friends, we've come to Philadelphia - the birthplace of our nation - because what happened in this city 240 years ago still has something to teach us today. We all know the story.(...)And by the time they left Philadelphia, they had begun to see themselves as one nation (Clinton, 2016a).

(2) Our Founders embraced the enduring truth that we are stronger together (Clinton, 2016a). 
(3) We have to decide whether we all will work together so we all can rise together. Our country's motto is e pluribus unum: out of many, we are one (Clinton, 2016a).

(4) The most enduring values. Freedom and equality, justice and opportunity. We should be so proud that these words are associated with us. That when people hear them - they hear... America (Clinton, 2016a).

The concept nation is introduced by its birthplace Philadelphia and, in such a way, it is implicitly personified being endowed with human characteristics of a person who was born. In addition, it is intensified by an adverb together (examples 2,3) used to characterise different predicates - actions and states (work, rise, be). Together expresses affect of security of positive disposition. In political discourse such evaluative attitude obviously construes a high degree of integration, which is facilitated by a pronoun we/us/our (examples 1, 2, 3, 4) performing an inclusive function: We - our values - America. Such evaluative meanings help unite aspirations of all Americans for achieving common aims.

The speaker also expresses some positive judgements: enduring truth is judgement of social sanction of propriety (example 2), which is also used as superlative most enduring values (example 4). Stronger is judgement of social esteem of capacity used in comparative form. One more example of evaluation is should, which expresses judgement of social sanction of propriety and proud - judgement of social esteem of tenacity (example 4). Moreover, the concept diversity is introduced by the motto out of many, we are one.

The use of such bonds contributes to the "value of political legitimacy" and intensifies the confidence of voters (Mulligan, 1998, p. 171). In other words, it helps create messages which are believed in by all members of the community.

\subsection{The category of Engagement}

Evaluation is a category predetermined by subjective segmentation of the world which is based not on the real characteristics of objects and phenomena but only on speakers' subjective impressions and emotional reactions to them (Arutyunova, 1988, p. 43). In such a way, evaluation is intended to produce an impact on the addressee, expressing mainly not a semantic but a pragmatic aspect of the communicative situation. Evaluating predicates are characterised by an illocutionary force, which can be elaborated in the communicative situation (Arutyunova, 1988, p. 44).

When speakers express some evaluation, directly or indirectly, they get bound to this kind of recommendation and take the responsibility for the consequences of following it. Such component makes evaluative statements similar to imperatives (Arutyunova, 1988, p. 46). In this context of primary importance are axiological predicates, included into the structure of evaluation. They add explicit subjectivity to the utterance, pointing out the subject of evaluation and linking it to the object of evaluation, which belongs to the conceptual world of the speaker (Prihod'ko, 2013, p. 34).

Mulligan suggests that no axiological property can be identified with some natural properties. But it's possible to suggest that possession of some "thick" axiological property entails possession of certain natural properties (Mulligan, 1998, p. 162). In addition, there is an interrelation between emotional experience and the use of axiological predicates. Emotions perform the function of the paradigmatic justifiers of the application of the predicates. Such relations of justification are called possession of axiological concepts (Mulligan, 1998, p. 164).

Axiological predicates can be represented by verbs expressing opinions, feelings, verbs of reporting which may perform two functions: determining a mental process and being used as modal words qualifying the ideas of the utterances (Hooper, 1973, p. 477). In the latter case, axiological predicates express an evaluative meaning conveyed in the utterance and show a certain attitude of the speaker to the contents of the utterance through a lexical meaning (Wolf, 2002, p. 34). In speech acts, the second function, defined as parenthetical, plays an important role. Predicates of opinion may perform this function not only in parenthetic phrases but also in other cases when they are used in the utterances delivered from the 1st person singular. Such predicates emphasise an evaluative meaning actually presented as an individual opinion (Wolf, 2002, p. 100).

The Appraisal theory, besides the use of axiological predicates, introduces a more comprehensive approach to the study of the speakers' contribution to the communication. The category of engagement, focusing on different responses and alternative viewpoints, is represented by the following meanings: disclaim, proclaim, entertain and attribute (Martin \& White, 2005, p. 97-98). This category extends a traditional approach to the study of modality, epistemic modality and evidentiality by focusing on the speaker's voice in relation to the voices of other interlocutors (Martin \& White, 2005, p. 94). In other words, what is of interest is dialogic perspective in the analysis of the speaker's contribution to communication. In Clinton's speeches, we may find quite a lot of examples of disclaiming her opponent's statements by means of denying and counteracting them. 
(5) Disclaim: Denials

None of us can raise a family, build a business, heal a community or lift a country totally alone (Clinton, 2016a).

Negation used in the initial position of this utterance refers to deontic modality, which expresses locutions concerned with permission and obligation. In this context, it is closely connected with moral values observed in the society (one nation, one community with democratic values), because implication can be done in terms of 'must consider/do' (Vignax, 1992, p. 35). It is a powerful denial of her opponent's position at deep moral level, as Donald Trump claimed that he would be able to fix the situation alone.

(6) And I don't think Mr. Trump understands any of it. He hasn't offered any credible solutions for the very real economic challenges we face (Clinton, 2016b).

As we know, negation is not just grammatical means used to express an opposite opinion but more often, especially in political discourse, it becomes influential means of argumentation (Belova, 2003, p. 224). Negation as a predicate category, which is associated with perceptions about wrong and right. It is likely to appear in the consciousness of a speaker simultaneously with modality, following the formation of basic predicate involved in the creation of the core of proposition (Stepanov, 1981, p. 320). In this example, Clinton expresses her opinion that her opponent doesn't understand the current economic situation in the country. Besides, he is not ready to offer any credible solutions to people. The negation is intensified by judgement of capacity.

(7) Disclaim: Counters

And according to an independent analysis by a former economic advisor to Senator John McCain, if you add up all of Trump's ideas - from cutting taxes for the wealthy and corporations, to starting a trade war with China, to deporting millions of hard-working immigrants - the result would be a loss of 3.4 million jobs. By contrast, the same analyst found that with our plans, the economy would create more than 10 million new jobs (Clinton, 2016b).

In this example, on the one hand, the meaning of attribute is expressed, when the speaker offers a reference to an external source - economic advisor. Actually, it is an acknowledgement of his analysis of Trump's economic ideas, which shows high loss of jobs in nearest future. On the other hand, counteraction is conveyed by conjunction by contrast and introduces Clinton's anticipated results in the economy, contrary to her opponent's ones - creation of a great number of jobs.

(8) Attribute

Even conservative experts say Trump's agenda will pull our economy back into recession (Clinton, 2016b).

One more example of acknowledgement illustrates reference to the opinion of conservative analysts. It's a crucial arguement against Trump because as a member of the Conservative party he fails to gain their support.

(9) A great Democratic President, Franklin Delano Roosevelt, came up with the perfect rebuke to Trump more than eighty years ago, during a much more perilous time. "The only thing we have to fear is fear itself"' (Clinton, 2016a).

An attribute can be expressed indirectly, conveying the meaning of distance (Martin and White, 2005, p. 113). In this utterance, there is a reference to well-known American president Franklin Roosevelt, whose opinion is introduced indirectly by means of an affect of dissatisfaction (rebuke) towards Trump. It's quite obvious that Trump has never met Roosevelt as they belong to different historical epochs. But in this formulation, there is no doubt that if a great president lived today, he would be disappointed by Trump's vision and would never support him. Roosevelt's authoritative opinion is created also by the meaning of appreciation of valuation (great), emphasising his role in the history of the country.

(10) Entertain

I believe America thrives when the middle class thrives. I believe that our economy isn't working the way it should because our democracy isn't working the way it should (Clinton, 2016c).

(11) And here at Futuramic - so well named - you are on the front lines of what I believe will be a true manufacturing renaissance in America (Clinton, 2016b).

The meaning of entertain expresses an individual subjective view, which can be treated as one of a range of possible positions (Martin \& White, 2005, p. 109). The speaker very often uses the phrase I believe (example 10) to show the things which are very important not only for the speaker but for all members of the community. It expresses Clinton's high degree of faith and confidence, and her commitment to this viewpoint. The presidential candidate, delivering her economic speech at Futuramic Tool and Engineering in Michigan, emphasises the importance of industrial revival of the country (example 11). Besides the use of axiological predicate, a metaphor front lines is of interest. It is an example of the so-called WAR metaphor (Lakoff, 2003, p. 65) widely used by politicians as a tool of persuasion. Such cognitive metaphors are wellaccepted and they don't violate people's perception or actions because they are used to construct and interact 
with reality (Goatly 2007, p. 22). WAR sphere is familiar to the audience, it demands decisive actions and excludes any compromises. That is why the field of manufacturing is easily embedded into this mental pattern creating intended associations in the minds of the audience.

(12) I think we need comprehensive background checks, need to close the on-line loophole, close the gun show loophole. There are other matters that I think are sensible that are the kind of reforms that would make a difference that are not in any way conflicting with the Second Amendment (Clinton, 2016e)

The phrase I think used in evaluative meaning performs a deliberative function and expresses an authority of the speaker (Martin \& White, 2005, p. 108). Clinton speaks about her vision of gun control and her support of the Second Amendment. She sounds rather persuasive, repeatedly using I think to express her subjective view on this issue.

(13) I know that's true, I did it as First Lady, Senator, and Secretary of State. It's how we created the Children's Health Insurance Program, which covers 8 million kids. It's how we rebuilt New York after 9/11, and how we passed a treaty reducing the threat from Russia's nuclear weapons. So I am convinced based on my experience, that we can do this (Clinton, 2016d).

There is also a wide use of an axiological predicate know, with the help of which verifiable proposition can be expressed. It may create an affective environment. The phrase $\boldsymbol{I}$ know can be treated as a set expression which describes an epistemic state of assuredness of the speaker (Belova, 2003, p. 266). Expressing true knowledge or categoric certainty, the phrase $\boldsymbol{I}$ know becomes a characteristic feature of an authoritative speaker with social and status domination. In this example, the speaker shares her experience of effective administrative management. In the end, a higher degree of certainty is expressed by means of I am convinced, an explicitly subjective modal assessment, which shows strong commitment of the speaker to her position.

The category of engagement provides one more meaning - proclaim, which can be conveyed by means of concurrence, pronouncement, and endorsement. In these cases, a proposition is represented as highly reliable, plausible, well-grounded, and valid.

(14) Proclaim: Concurrence

So many states are putting very stringent regulations on women that block them from exercising that choice to the extent that they are defunding Planned Parenthood, which, of course, provides all kinds of cancer screenings and other benefits for women in our country (Clinton, 2016e).

The speaker tackles one of the most controversial issues for the society: abortion and birth control. Clinton supports Planned Parenthood and abortion legitimacy (Roe v. Wade) and points out the advantages of this programme by means of using of course, which signals of a highly reliable position of the speaker. The speaker expresses negative judgement of veracity (stringent), speaking about regulations that many states have to demonstrate that her opinion is right.

(15) Proclaim: Pronouncement

You can really feel the energy and dynamism that is driving this state's comeback (Clinton, 2016b).

(16) And here's something else I really want to emphasize, because I don't think anyone in America is talking about this enough and that is: a four year degree should not be the only path to a good job in America (Clinton, 2016b).

Pronouncements usually introduce a speaker's involvement into communication to assert a proposition subjectively (I conclude, I mean, I agree) or objectively with more neutral phrases (the truth is, the fact is, really). The Democratic presidential nominee highlights the driving forces of national economic revival using really as an objective realisation option for her pronouncement (example 15). We may also indicate positive judgement of capacity (energy, dynamism), which characterises the changes in the country. In example 16 besides really, she uses infused intensification (emphasise) and a causative predicate (want) to show the importance of her reforms in education.

(17) Proclaim: Endorsement

Because all the people that I've met in this campaign really prove how wrong this negative, pessimistic view is (Clinton, 2016b.)

(18) Because Roe $v$. Wade very clearly sets out that there can be regulations on abortion so long as the life and the health of the mother are taken into account (Clinton, 2016e).

In endorsement utterances, the speaker gives some grounds to support her ideas. Clinton sharply criticizes Trump's vision of the USA, which witnesses a period of stagnation (example 17). She mentions that a lot of Americans do not support this approach, expressing the meaning of endorsement by prove. Clinton stands her grounds about abortion permission (example 18) and makes it clear by recalling a historically crucial court decision for abortions (set out). 


\subsection{Intensification of Evaluation}

Something is valuable if it is possible for it to be the object of an appropriate emotion (Mulligan, 1998, p. 170). In the framework of Appraisal theory graduation includes a variety of intensification means, which can be divided into ones created by force or by focus. A general example of gradable judgement is: reasonably good - quite good - very good - extremely good (Martin \& White, 2005, p. 136). Intensification of meaning according to the up/down scale is indiscreet, in other words, not limited by the number of positions (Wolf, 2002, p. 45). Taking into consideration the results of psycholinguistic research, Wolf identifies the following elements in the scale: very good-good-good enough-satisfactory - bad enough - bad - very bad (Wolf, 2002, p. 52). In political discourse, especially in election campaigns in the competition for votes, discursive strategies of positive self-presentation and negative other-presentation are widely used. They are commonly based on semantic and ideological polarisation (van Dijk, 1997, p. 28). It's evident that evaluative elements used to describe the politician and his her party will tend to up-scaling, while negative evaluative elements of down-scaling are usually opted for opponents.

(19) Americans don't say: "I alone can fix it." We say: "We'll fix it"(Clinton, 2016a).

Clinton criticises her opponent, Trump. On the one hand, Clinton associates herself to America by using inclusive we. In this case, it becomes quite clear that her opponent is opposed not only by her but by the whole society. On the other hand, she opposes Trump's strategy to solve all problems alone as it contradicts the fundamental principles of American democracy of building the united nation which can cope with the challenges with the help of all members (I//WE).

(20) Let's make sure this economy works for everyone, not just those at the top (Clinton, 2016c).

Then the criticism being expressed about Trump's ideology, Clinton as a member of Democratic party emphasises that economy works for everyone, not just those at the top. It means that the interests of all people must be considered by a future president. Implicitly there is an indication that Trump backs only those who are at the top with high income.

(21) Now, you didn't hear any of this from Donald Trump at his convention. He spoke for 70-odd minutes - and I do mean odd. And he offered zero solutions. But we already know he doesn't believe these things. No wonder he doesn't like talking about his plans. You might have noticed, I love talking about mine. In my first 100 days, we will work with both parties to pass the biggest investment in new, goodpaying jobs since World War II (Clinton, 2016a).

In this example Clinton describes her opponent's communicative behaviour, using negative judgement of normality odd minutes, which is repeatedly used and intensified by emphatic do. Zero solutions is one more negative judgement of his campaign. Then, there is a grammatical polarisation about their plans $\boldsymbol{h} \boldsymbol{e}$ doesn't like talking about his plans // I love talking about mine. Her own contribution to-national economy Clinton describes with the help of intensification of meaning, superlative biggest investment and appreciation of positive valuation new, good-paying jobs since World War II. So, the use of negative judgement on Trump, on the one hand, and positive appreciation about her own plans, on the other hand (odd, zero solutions // the biggest, good-paying), help create the polarised picture with the emphasis on personal achievements.

(22) The answer is to finally make trade work for us, not against us (Clinton, 2016c).

In this utterance, the speaker draws attention of the audience to the future trade strategies of her opponent. The inference created by polarisation of vision (for us// against us) makes people believe that Trump is not able to arrange successful trade contracts for the country.

In general, Clinton uses a wide variety of positive axiological operators and superlatives as graduation by force, when she speaks about American society and its future.

(23) It was about the country we love and building an America that is hopeful, inclusive and bighearted (Clinton, 2016f).

The image of America is depicted by means of the positive judgement of normality (inclusive), of propriety (big-hearted) and appreciation of valuation (hopeful).

(24) We have the most dynamic and diverse people in the world. We have the most tolerant and generous young people we've ever had. We have the most powerful military. The most innovative entrepreneurs (Clinton, 2016a).

In this example there is a parallel syntactic construction We have + superlative + Noun, which is repeated four times. Repetition is known as one of the modes of intensification of meaning (Martin \& White, 2005 , p. 144). By means of parallelism, the most essential advantages and the great potential of the country are emphasised. The repeated use of superlatives: a positive judgement of capacity (dynamic, diverse, powerful), of propriety (tolerant, generous) and appreciation of valuation (innovative) makes the speech of 
the politician rather emphatic and quite impressive. It creates an emotional appeal to the society and, as a result, makes its members become proud of their achievements.

\subsection{Metaphors}

Speakers use a wide variety of expressive means in political discourse to achieve their main pragmatic goal, in particular, to persuade the audience that their point of view is the only correct one and, in such a way, to win more votes (Cherednichenko, 2007, p. 57). The function of expressive means and stylistic devices is to make an impact not on the rational but on the emotional-associative mentality of people with the aim to get their confidence. It is known that in addition to rational logic there are peripheral routes of persuasion related to emotional appeals (Mio, 1997, p. 121). Metaphors stir emotions because they touch latent cognitive structures. When emotions are evoked, logic is paralysed (Mio, 1997, p. 122). Metaphors as one of the forms of symbolic representation are also used in political discourse to give shape to argumentation and intensify the intended meaning. Metaphors can make difficult issues understandable and relevant to the general public. This makes public feel as a part of political processes and supports the speaker (Thompson, 1996).

In the Cognitive Metaphor Theory metaphors are treated as cognitive mechanisms for processing abstract subjective notions with the help of concrete physical experiences based on perception (Lakoff \& Johnson, 2003, p. 19). Appraisals are cognitive evaluations that individuals perform when they encounter triggers in their environment (Bednarek, 2009, p. 154). But Deignan also claims that there is an extension to such definition because the use of metaphor is influenced by other factors, such as linguistic, genre, cultural and ideological. That is why being cognitive, metaphor is also a textual and social phenomenon (Deignan, 2005, p. 124). Within the framework of Appraisal theory metaphors are one of means of intensification of evaluative meaning (Martin \& White, 2005, p. 143). The speeches of the Democratic presidential candidate are rather metaphorically-oriented.

(25) How are you going to break through the gridlock in Washington? Look at my record. I've worked across the aisle to pass laws and treaties and to launch new programs that help millions of people (Clinton, 2016a).

Sharing her plans with the public, H. Clinton admits that it would be difficult to implement everything, all planned reforms, describing the current situation as a gridlock. But at the same time, she emphasizes that she has managed to do a lot, her record as a negotiator being impressive I've worked across the aisle. In such a way, the audience should undoubtedly infer that she as a president will manage to succeed.

(26) Bernie, your campaign inspired millions of Americans, particularly the young people who threw their hearts and souls into our primary (Clinton, 2016a). You poured your hearts into this campaign (Clinton, 2016f).

The speaker emphasises the essential contribution to the election campaign made by her supporters. The use of HEART metaphors for expressing her gratitude and appreciation appeal to the audience is rather symbolic. Heart is known to be associated with feelings and love. Feelings are figuratively located in heart in the opposition to head, the place where reason is conventionally placed (Perez, 2008, p. 31). In addition, love (as a word and a concept corresponding to it) is considered to be one of basic emotion words (Kovecses, 2004, p. 3). In this context, it evokes the idea that Clinton's supporters gave reign to their feelings and were led more by their devotion to the party than by reason and deliberate consideration.

(27) I know we have still not shattered that highest and hardest glass ceiling, but some day someone will - and hopefully sooner than we might think right now (Clinton, 2016f).

No less essential is the use of metaphor to shatter glass ceiling which means to overcome gender discrimination at work when promotion is more preferably given to men. Taking into consideration Trump's offensive expressions about women, it implicitly may establish certain associations with politically incorrect behaviour of her opponent.

(28) He thinks that he knows more than our military because he claimed our armed forces are a “disaster". I know how wrong he is. Our military is a national treasure (Clinton, 2016a).

It is pointed out that a metaphorical utterance is one of the means of optimising relevance. But it can be optimally relevant only when it shares the logical and contextual implications of a speaker, and an audience is ready to sort out all implications that the speaker wants to endorse. When a metaphor is used in a particular context, a speaker is aware that an audience might be in sympathy with such arguement (Mio, 1997, p. 123), and, as a result, it makes a speaker closer to an audience. Clinton continuously uses semantic polarisation based on metaphorical expressions, demonstrating high degree of her dissatisfaction with Trump's strategies. Metaphorical expressions disaster and national treasure, used in relation to military forces, occupy diametrically opposite points on the evaluation scale. They form the audience's perceptions about the disrespect that her opponent exhibits in relation to the army. As a consequence, it might lead to his loss of the public support. 
More metaphors with negative connotation are used to describe Trump's intentions "to fix it alone", to be able to do everything himself.

(29) Donald Trump can't even handle the rough-and-tumble of a presidential campaign (Clinton, 2016a).

In this utterance, a metaphor the rough-and-tumble is used to show that a presidential candidate may face a lot of different challenges during an election race. Trump fails to overcome such difficulties as his campaign is accompanied by various arguements and conflicts.

(30) But the answer is not to rant and rave - or cut ourselves off from the world. That would end up killing even more jobs (Clinton, 2016b).

Speaking about Trump's intention to close the borders from illegal migrants and refugees, Clinton describes his behaviour as to rant and rave, which is not reasonable for a serious politician. More metaphors with negative connotation cut ourselves off from the world, killing even more jobs are used to describe the results of this decision. All of them create a negative emotional background and obviously make the audience perceive an intended implication.

\section{Conclusion}

Having analysed a corpus of data comprising more than 400 lexical units which express a range of evaluative meanings, we may make a conclusion that Hillary Clinton demonstrates a high degree of evaluation as a speaker in the context of the presidential election race. Evaluation in the political discourse of the Democratic candidate is highly predetermined by cultural, all-national values, which are represented by semantic bonds.

As for attitudinal meanings, her discourse expresses more judgement - assessment of capacity (65), propriety (50) and veracity (48) than the meanings of appreciation (42) or affect (37). We may suggest that the speaker is more governed by reason and deliberation than by emotions and feelings in communication with the potential voters. Semantic polarisation is widely used as means of intensifying evaluation and emphasising the fact that Donald Trump isn't worth voting for. It starts at the conceptual level to which the opposition I//We belongs. It is an opposition of individualistic versus communal approaches, the first one being associated with Trump and the second one - with Clinton and America. Negative evaluation is mostly used to criticise Trump's plans, his behaviour and his attitude to people and society in general. Positive evaluative meanings are expressed to prove that the USA is a great country with promising future and to describe Clinton's vision of the country's future development. The speaker also demonstrates her contribution to the proposition and uses "involving mechanisms" to convey a wide variety of evaluative meanings under dialogistic engagement. The majority of them is represented by disclaiming (54) and entertaining (50). Intensification of evaluative meanings is performed, in particular, by means of metaphors in Clinton's speeches. As a rule, they are also used to persuade the audience that her opponent is unlikely to meet the expectations of voters. Besides, there are also HEART metaphors which add positive attitudinal evaluation to the utterance, when Clinton speaks about her supporters. WAR metaphors convey the importance of crucial changes in the national economy.

It is obvious, that a category of evaluation is a complex phenomenon which should be studied from different perspectives. This paper is focused only on one aspect of evaluation related to various means of expressing affect, judgement and appreciation. But appraisal also involves some deep cognitive mechanisms which dominate in a certain cultural environment. That is why a further research based on correlation of linguistic and cognitive approaches to the study of evaluation can be possible. No less important is to consider communicative intentions and goals of speakers, their motivation and temporality of evaluation. The relationships between a speaker and the object of evaluation also deserve thorough attention of researchers. It makes the pragmatic aspect of evaluation relevant for further analysis.

\section{References:}

Arutyunova, N.D. (1988). Tipy iazykovyh znacheniiy. Otsenka. Sobytie. Fakt [Types of Language Meanings. Evaluation. Event. Fact]. Moscow: Nauka.

Bednarek, M. (2009). Dimensions of evaluation: Cognitive and linguistic perspectives. Pragmatics \& Cognition, 17(1), 146-175. https://doi.org/10.1075/pc.17.1.05bed

Belova, A. D. (2003). Lingvisticheskie aspecty argumentatsii [Linguistic Aspects of Argumentation]. Kyiv: Logos.

Byessonova, O. (2012). Reconstruction of Value Concepts in the Language Model of the World. In: Ferencik, M. \& BednarovaGibova, K. (Eds.), Language, Literature and Culture in a Changing Transatlantic World II. Part I: Lingustics, Translation and Cultural Studies (pp.7-14). Preskov, Bulgaria.

Cherednichenko, A. I. (2007). Pro movu i pereklad [On Language and Translation]. Kyiv: Lybid'.

Clinton, H. (July 29, 2016a). Speech at the Democratic Convention. Retrieved July 20, 2017, from https://www.nytimes.com/2016/0 7/29/us/politics/hillary-clinton-dnc-transcript.html

Clinton, H. (August, 11, 2016b). Economic Speech. Retrieved July 20, 2017, from http://www.newsweek.com/hillary-clinton-fulltranscript-economic-speech-489602html 
Clinton, H \& Trump, D. (September, 26, 2016c). The First Debate transcript. Retrieved July 21, 2017, from https://www.washington post.com/news/the-fix/wp/2016/09/26/the-first-trump-clinton-presidential-debate-transcriptannotated/?utm_term $=.3 \mathrm{bcb} 8204 \mathrm{~b} 2 \mathrm{a} 9$

Clinton, H. \& Trump, D. (October, 09, 2016d). The Second Debate. Retrieved July 20, 2017, from https://www.nytimes.com/2016/10 /10/us/politics/transcript-second-debate.hml

Clinton, H. \& Trump, D. (October, 19, 2016e). The Final Debate transcript. Retrieved July 19, 2017, from https://www.washingtonp ost.com/news/the-fix/wp/2016/10/19/the-final-trump-clinton-debate-transcript-annotated/?utm_term=.386b4336abeb

Clinton, H. (November 09, 2016f). Concession Speech. Retrieved July 20, 2017, from http://fortune.com/2016/11/09/hillary-clintonconcession-speech-transcript/

Deignan, A. (2005). Metaphor and Corpus Linguistics. Amsterdam, Philadelphia: John Benjamins.

Fairclough, N. (1995). Critical Discourse Analysis: Papers in the Critical Study of Language. London: Longman.

Fitzwater, M. (2016). I do not think there is a quick fix. Civility in Presidential Election Discourse. Rindge, New Hampshire: Franklin Pierce University, 6-7.

Fraser, B. (1996). Pragmatic Markers. Pragmatics, 6(2), 167-190. https://doi.org/10.1075/prag.6.2.03fra

Goatly, A. (2007). Washing the brain. Amsterdam, Philadelphia: John Benjamins.

Halliday, M. A. K. (2002). Linguistic Studies of Text and Discourse. In: Webster J. (Ed.), The collected works of M.A.K. Halliday Series, V. 2. London, New York: Continuum.

Hart, C. (2014). Discourse, Grammar and Ideology: Functional and Cognitive Perspectives. London, New York: Academic.

Hofstede, G. (2011). Dimensionalizing Cultures: The Hofstede Model in Context. Online Readings in Psychology and Culture, 2(1). https://doi.org/10.9707/2307-0919.1014

Hooper J.B. \& Thompson, S.A. (1973). On the Applicability of Root Transformations. Linguistic Inquiry, 4 (4), $465-497$.

Karasik, V. (2004). Iazykovoi Krug: Lichnost', Kontsepty, Diskurs [Language Circle: Personality, Concepts, Discourse]. Moscow: Gnosis.

Kovecses, Z. (2004). Metaphor and Emotion. Language, Culture, and Body in Human Feeling. Cambridge: Cambridge University Press.

Lakoff, G., Johnson, M. (2003). Metaphors we live by. Chicago: University of Chicago Press. https://doi.org/10.7208/chicago/97802 26470993.001.0001

Malrieu, J. P. (1999). Evaluative Semantics. Cognition, Language, and Ideology. London, New York: Routledge.

Martin, J. R., White P. R.R. (2005). The Language of Evaluation. Appraisal in English. New York: Palgrave Macmillan.

Maslow, A. H., (1999). Motivatsia i lichnost [Motivation and Personality]. Saint Petersberg, Russia: Euroasia.

McKeever, K. (2016). Words Matter: The Why, When, and Where of Civil Discourse. In Civility in Presidential election Discourse (pp.3-4). Rindge, New Hampshire: Franklin Pierce University.

Mio, J. S. (1997). Metaphor and Politics. Metaphor and Symbol, 12(2), 113-133. https://doi.org/10.1207/s15327868ms1202_2

Mulligan, K. (1998). From Appropriate Emotions to Values. The Monist, 81(1), 161-188. https://doi.org/10.5840/monist199881114

Perez, R. Q. (2008). A Cross-Cultural Analysis of Heart Metaphors. Revista Alicantina de Estudies Ingleses, 21,25 -56. https://doi.org/10.14198/raei.2008.21.03

Pryhod'ko, G.I. (2013). Otsinka i komunikatsiia [Evaluation and Communication] . Vinnytsa: Nova Knyha.

Sillars, M. O., Ganer, P. (1982). Values and Beliefs: A Systemic Basis for Argumentation. In: Cox J. R., Charles A. W. (Eds.), Advances in Argumentation Theory and Research (pp.184-201). Carbondale: Southern Illinois University Press.

Sinclair, J.M. (2004). Trust the Text: Language, Corpus and Discourse. London: Routledge. https://doi.org/10.4324/9780203594070

Schaffner, C., Wenden, A. (1995). Language and peace. Dartmouth: Aldershot.

Sheigal, E. (2000). Semiotika politicheskogo diskursa [Semiotics of Political Discourse]. Volgograd: Peremena.

Short, M., Semino, E. (2008). Evaluation and Stylistic Analysis. In: Van Peer W. (Ed.), The Quality of Literature: Linguistic Studies in Literary Evaluation (pp.117-138). Amsterdam: John Benjamins Publishing Co. https://doi.org/10.1075/lal.4.09sho

Stepanov, Y. (1981). Imena, Predikaty, Predlozheniya [Names, Predicates, Sentences]. Moscow: Nauka.

Wierzbicka, A. (2006). English: Meaning and Culture. Oxford: Oxford University Press.

Thompson, S. (1996). Politics without metaphors is like a fish without water. In: Mio J.S., Kats A.N. (Eds.), Metaphor: Implications and Applications (pp.185-201). Mahwah, NJ: Lawrence Erlbaum Associates.

Van Dijk, T. A. (1997). What is Political Discourse Analysis? Belgian Journal of Linguistics, 11(1), 11-52. https://doi.org/10.1075/bjl.11.03dij

Vignaux, G. (1992). From Negation to Notion: Cognitive Process and Argumentative Strategies. Argumentation, 6 (1), $29-39$. https://doi.org/10.1007/BF00154257

White, P. R.R., (2015). Appraisal Theory. In: Tracy, K. (Ed.). The International Encyclopedia of Language and Social Interaction. John Wiley \& Sons. http://doi.org/10.1002/9781118611463.wbielsi041

Wolf, E. (2002). Funktsionalnaia semantika otsenki [Functional Semantics of Evaluation]. Moscow: Editorial URSS.

Zhabotynska, S. (2013). Imya kak tekst: kontseptualnaya set' leksicheskogo znacheniya (analiz imeni emotsii) [The name as a text: conceptual network of lexical meaning (analysis of the name of emotion)]. Kognitsiya, Kommunikatsia, Diskurs, 6, 47-76. 